\title{
STRATEGI KEPEMIMPINAN KEPALA SEKOLAH DALAM MENINGKATKAN KINERJA GURU
}

\author{
Istikomah \\ Sekolah Tinggi Agama Islam (STAI) Yasni Muara Bungo \\ e-mail: istidani88@gmail.com
}

\begin{abstract}
Leadership is an important force in the framework of management. Therefore, effective ability is the key to being an effective manager. The achievement of educational goals depends very much on the skills and wisdom of the principal's leadership which is one of the leaders of education. Because the principal is a professional officer in the school organization who is responsible for managing all sources of the organization and cooperating with teachers in educating students to achieve educational goals. This article aims to find out and provide an overview of the actual concept of the principal's leadership strategy in improving teacher performance. The role of the principal's leadership is one of the most strategic steps in realizing educational goals. This article is the result of library research using descriptive analysis and approaches. The results of the analysis show that the leadership of the principal in improving the performance of teachers in schools can use several strategies: 1) the discipline development, namely the principal helps teachers to develop patterns and improve their practice standards as teachers, and use the implementation of rules as a tool to enforce discipline, 2) providing motivation to improve teacher performance, principals need to provide motivation to the teachers and other factors that can affect teacher performance, 3) awards, principals give awards to teachers who excel even though the award is by saying or praise.
\end{abstract}

Keywords: Strategy, Principal Leadership, Teacher Performance.

\begin{abstract}
Abstrak
Kepemimpinan adalah suatu kekuatan yang penting dalam rangka pengelolaan. Oleh sebab itu kemampuan secara efektif merupakan kunci untuk menjadi seorang manajer yang efektif. Ketercapaian tujuan pendidikan sangat bergantung pada kecakapan dan kebijaksanaan kepemimpinan kepala sekolah yang merupakan salah satu pemimpin pendidikan. Karena kepala sekolah merupakan seorang pejabat yang profesional dalam organisasi sekolah yang bertugas mengatur semua sumber organisasi dan bekerjasama dengan guru-guru dalam mendidik siswa untuk mencapai tujuan pendidikan. Artikel ini bertujuan untuk mengetahui dan memberikan gambaran tentang bagaimana sebenarnya konsep strategi kepemimpinan kepala sekolah dalam meningkatkan kinerja guru. Peranan kepemimpinan kepala sekolah
\end{abstract}

Nur El-Islam, Volume 5, Nomor 2, Oktober 2018 
merupakan salah satu langkah yang sangat setrategis dalam mewujudkan tujuan pendidikan. Artikel ini merupakan hasil penelitian kepustakaan dengan menggunakan pendekatan dan analisis deskriptif. Hasil analisis menunjukkan bahwa kepemimpinan kepala sekolah dalam meningkatkan kinerja guru di sekolah bisa menggunakan beberapa strategi: 1) pembinaan disiplin, yaitu kepala sekolah membantu para guru untuk mengembangkan pola dan meningkatkan standar prilakunya sebagai guru, serta menggunakan pelaksanaan aturan sebagai alat untuk menegakkan disiplin, 2) pemberian motivasi untuk meningkatkan kinerja guru, kepala sekolah perlu memberikan motivasi kepada para guru dan faktor lain yang dapat mempengaruhi kinerja guru, 3) penghargaan, kepala sekolah memberikan penghargaan kepada guru yang berprestasi walaupun penghargaan itu dengan ucapan atau pujian.

Kata kunci: Strategi, Kepemimpinan Kepala Sekolah, Kinerja Guru.

\section{A. Pendahuluan}

Salah satu persoalan pendidikan yang sedang dihadapi bangsa adalah persoalan mutu pendidikan pada setiap jenjang dan satuan pendidikan. Berbagai usaha telah dilakukan untuk meningkatkan mutu pendidikan nasional, antara lain melalui berbagai pelatihan dan peningkatan kompetensi guru, pengadaan buku dan alat pelajaran, perbaikan sarana dan prasarana pendidikan, dan meningkatkan mutu manajemen sekolah. Namun demikian, indikator mutu pendidikan belum menunjukkan peningkatan yang berarti. Sebagian sekolah, terutama di kota-kota, menunjukkan peningkatan mutu pendidikan yang mencakup menggembirakan, namun sebagian besar lainnya masih memprihatinkan.

Kepemimpinan adalah suatu kekuatan yang penting dalam rangka pengelolaan. Oleh sebab itu kemampuan secara efektif merupakan kunci untuk menjadi seorang manajer yang efektif. Esensi kepemimpinan adalah kepengikutan (followership), yaitu kemauan orang lain atau bawahan untuk mengikuti keinginan pemimpin. Itulah yang menyebabkan seseorang menjadi pemimpin. Dengan kata lain, pemimpin tidak akan terbentuk apabila tidak ada bawahan. Jadi, kepala sekolah sebagai seorang pemimpin harus mampu:

a. Mendorong timbulnya kemauan yang kuat dengan penuh semangat dan percaya diri para guru, staf dan siswa dalam melaksanakan tugas masing-masing. 
b. Memberikan bimbingan dan mengarahkan para guru, staf dan para siswa serta memberikan dorongan memacu dan berdiri di depan demi kemajuan dan memberikan inspirasi sekolah dalam mencapai tujuan. ${ }^{1}$

Kepemimpinan yang baik tentunya sangat berdampak pada tercapai tidaknya tujuan organisasi karena pemimpin memiliki pengaruh terhadap kinerja yang dipimpinnya. Kemampuan untuk mempengaruhi suatu kelompok untuk mencapai tujuan merupakan bagian dari kepemimpinan. Konsep kepemimpinan erat sekali hubungannya dengan konsep kekuasaan. Dengan kekuasaan, pemimpin memperoleh alat untuk mempengaruhi perilaku para pengikutnya. Terdapat beberapa sumber dan bentuk kekuasaan, yaitu kekuasaan paksaan, legitimasi, keahlian, penghargaan, referensi, informasi, dan hubungan. ${ }^{2}$

Kepala sekolah akan berhasil apabila mereka memahami keberadaan sekolah sebagai organisasi yang kompleks dan unik, serta mampu melaksanakan peranan kepala sekolah sebagai seorang yang diberi tanggung jawab untuk memimpin sekolah. Betapa penting peranan kepala sekolah dalam menggerakkan kehidupan sekolah untuk mencapai tujuan, ada dua hal yang perlu diperhatikan dalam mencapai tujuan tersebut, yaitu:

a) Kepala sekolah berperan sebagai kekuatan sentral yang menjadi kekuatan penggerak kehidupan sekolah.

b) Kepala sekolah harus memahami tugas dan fungsi mereka demi keberhasilan sekolah, serta memiliki kepedulian kepada staf dan siswa. $^{3}$

Disinilah tampak secara jelas peranan kepala sekolah sebagai pemimpin pendidikan. Para kepala sekolah yang mendapat kepercayaan memimpin sekolah, perlu menyenangi dan menyintai pekerjaan yang terkait dengan tugas dan tanggung jawab yang

1 Wahjosumidjo, Kepemimpinan Kepala Sekolah, Tinjauan Teoritik dan Permasalahanya (Jakarta: Rajawali Pres, 2013), Cet. 9, h. 104-105.

${ }^{2}$ Miftah Toha, Kepemimpinan Dalam Manajemen (Jakarta: Rajawali Pers, 2010), h. 323.

${ }^{3}$ Wahjosumidjo, Kepemimpinan Kepala Sekolah, h. 81-82. 
dipercayakan kepadanya. Kepala sekolah perlu menyusun program yang mempunyai daya tarik berkaitan dengan mutu sekolah. ${ }^{4}$

Dari pada itu, di dalam organisasi juga membutuhkan pegawai atau tenaga kependidikan yang dapat membantu pelayanan administrasi bagi sekolah khususnya pelanggan. Maksud pelanggan di sini adalah peserta didik, orang tua siswa dan orang-orang yang terlibat dalam organisasi. Tenaga kependidikan yang dimaksud di sini adalah guru yang bekerja dilingkungan pendidikan atau sekolah dengan tujuan memperoleh prestasi dan kualitas sekolah.

Suasana yang harmonis di sekolah tidak akan terjadi bila personil yang terlibat didalamnya, yakni kepala sekolah, guru, staf administrasi dan siswa, tidak menjalin hubungan yang baik diantara sesamanya. Penciptaan suasana kerja menantang harus dilengkapi dengan terjalinnya hungan yang baik dengan orang tua dan masyarakat sekitarnya. Ini dimaksudkan untuk membina peran serta dan rasa tanggung jawab bersama terhadap pendidikan. ${ }^{5}$

Kepala Sekolah mempunyai peranan pimpinan yang sangat berpengaruh di lingkungan sekolah yang menjadi tanggung jawabnya. Tugas kepala sekolah selaku pemimpin ialah membantu para guru mengembangkan kesanggupan-kesanggupan mereka secara maksimal dan menciptakan suasana hidup sekolah yang sehat yang mendorong guru-guru, pegawai-pegawai tata usaha, murid-murid dan orang tua murid untuk mempersatukan kehendak, pikiran dan tindakan dalam kegiatan-kegiatan kerja sama yang efektif bagi terciptanya tujuantujuan sekolah. ${ }^{6}$

Dengan keprofesionalan kepala sekolah ini pengembangan profesionalisme tenaga kependidikan mudah dilakukan karena sesuai dengan fungsinya, kepala sekolah memahami kebutuhan sekolah yang ia pimpin sehingga kompetensi guru tidak hanya pada kompetensi

${ }^{4}$ Saiful Sagala, Manajemen Strategic Dalam Peningkatan Mutu Pendidikan (Bandung: Alfabeta, 2009), h. 93.

${ }^{5}$ Soetjipto dan Raflis Kosasi, Profesi Keguruan (Jakarta: PT Rineka Cipta, 1999), h. 51.

${ }^{6}$ M. Ngalim Purwanto, Administrasi dan Supervisi Pendidikan (Bandung: PT. Remaja Rosdakarya, 2008), h. 73-74. 
yang ia miliki sebelumnya, melainkan bertambah dan berkembang dengan baik sehingga profesionalisme guru akan terwujud. Karena tenaga kependidikan profesional tidak hanya menguasai bidang ilmu, bahan ajar, dan metode yang tepat, akan tetapi mampu memotivasi peserta didik, memiliki keterampilan yang tinggi dan wawasan yang luas terhadap dunia pendidikan.

Artikel ini merupakan hasil penelitian kepustakaan dengan menggunakan pendekatan dan analisis deskriptif. Sedangkan tujuan yang hendak dicapai dari penelitian tersebut adalah mengungkap bagaimana sebenarnya konsep strategi kepemimpinan kepala sekolah dalam meningkatkan kinerja guru. Sehingga dengan mengetahui dan memahami konsep tersebut diharapkan para kepala sekolah dapat menerapkan konsep tersebut dilapangan yang diintegrasikan dengan lingkungan setempat sebagai bagian bentuk dari perhatian dan tanggungjawab sebagai pemimpin.

\section{B. Pembahasan}

\section{Pengertian Strategi Kepemimpinan Kepala Sekolah}

Strategis kepemimpinan adalah tuntutan bagi pemimpin agar bersifat fleksibel dalam mengatasi sesuatu yang tidak diharapkan, dan tuntutan bagi mereka untuk mempunyai 'visi helikopter', yaitu suatu kemampuan untuk berpandangan jauh kedepan. ${ }^{7}$ Kepemimpinan strategis, sebaliknya, merupakan seni dan ilmu yang mengfokuskan perhatiannya pada kebijakan-kebijakan dan tujuan-tujuan dengan rencana-rencana jangka panjang. Kepemimpinan merupakan proses mengarahkan, membimbing, mempengaruhi, atau mengawasi pikiran, perasaan atau tindakan dan tingkah laku orang lain. Kepemimpinan yaitu tindakan atau perbuatan di antara perseorangan dan kelompok yang menyebabkan baik orang maupun kelompok bergerak ke arah tujuan tertentu.

Kepemimpinan merupakan kemampuan yang dipunyai seseorang untuk mempengaruhi orang-orang lain agar bekerja

\footnotetext{
7 Tony Bush dan Marianne Coleman, Manajemen Strategi Kepemimpinan Pendidikan,terj. Fahrurrozi (Yogyakarta: Ircisod, 2008), h. 91-93.
} 
mencapai tujuan dan sasaran. Kepemimpinan dapat diklasifikasikan sebagai pendekatan-pendekatan kesifatan, prilaku dan situasional (contingency) dalam studi tentang kepemimpinan. Pendekatan pertama memandang kepemimpinan sebagai suatu kombinasi sifat-sifat (traits) yang tampak. Pendekatan yang kedua bermaksud mengidentifikasikan perilaku-perilaku (behaviors) pribadi yang berhubungan dengan kepemimpinan efektif. Kedua pendekatan ini mempunyai anggapan bahwa seorang individu yang mempunyai sifat-sifat tertentu atau memperagakan perilaku-perilaku tertentu akan muncul sebagai pemimpin dalam situasi kelompok apapun dimana dia berada.

Pemikiran sekarang mendasarkan pada pendekatan ketiga, yaitu pandangan situasional tentang kepemimpinan. Pandangan ini menganggap bahwa kondisi yang menentukan efektifitas kepemimpinan bervariasi dengan situasi, tugas-tugas yang dilakukan, ketrampilan dan pengharapan bawahan, lingkungan organisasi, dan sebagainya. Pandangan ini telah menimbulkan contingency pada kepemimpinan, yang dimaksud untuk menetapkan faktor-faktor situasional yang menentukan seberapa besar efektifitas situasi gaya kepemimpinan tersebut. ${ }^{8}$ Kepemimpinan dapat dipergunakan setiap orang dan tidak hanya terbatas berlaku dalam suatu organisasi atau kantor tertentu. Kepemimpinan adalah kegiatan untuk mempengaruhi perilaku orang lain, atau seni memepengaruhi perilaku manusia baik perorangan maupun kelompok. ${ }^{9}$

Pada konteks pemimpin, Allah berfirman dalam Al-Qur'an surat An-Nisa' ayat 59.

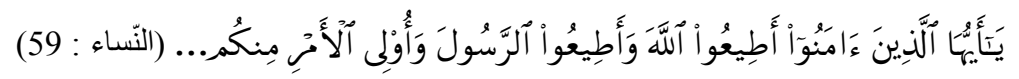

Artinya: "Hai orang-orang yang beriman, taatilah Allah dan taatilah Rasul (nya), dan ulil amri di antara kamu”. (Q.S. An-Nisa': 59) ${ }^{10}$

\footnotetext{
${ }^{8}$ T. Hani Handoko, Manajemen (Yogyakarta: BPFE, 2012), h. 294.

${ }^{9}$ Thoha, Kepemimpinan Dalam Manajemen, h. 9.

${ }^{10}$ Kementrian Agama RI, Al-Qur'an dan Terjemahnya (Semarang: PT. Thoha Putra, 2008), h. 88.
} 
Dalam tafsir Al-Maraghi diterangkan bahwa ulil amri yaitu para umara, hakim, ulama, panglima perang, dan seluruh pemimpin dan kepala yang menjadi tempat kembali manusia dalam kebutuhan dan maslahat umum. Apabila mereka telah menyepakati suatu urusan atau hukum, mereka wajib ditaati. Dengan syarat, mereka harus dapat dipercaya, tidak menyalahi perintah Allah dan sunnah Rasul yang mutawatir, dan di dalam membahas serta menyepakati perkara mereka tidak ada pihak yang memaksa. ${ }^{11}$

Kepala sekolah atau sekolah merupakan pimpinan tertinggi di sekolah. Pola kepemimpinannya akan sangat berpengaruh bahkan sangat menentukan terhadap kemajuan sekolah. Oleh karena itu, pada pendidikan modern, kepemimpinan kepala sekolah perlu mendapat perhatian secara serius. Keberhasilan suatu lembaga pendidikan sangat tergantung pada kepemimpinan kepala sekolah.

Adapun standar kompetensi kepala sekolah yaitu:

a. Kompetensi kepribadian

b. Kompetensi manajerial

c. Kompetensi kewirausahaan

d. Kompetensi supervise

e. Kompetensi sosial ${ }^{12}$

Bentuk atau gaya kepemimpinan adalah sekumpulan ciri yang digunakan pimpinan untuk mempengaruhi bawahan agar sasaran organisasi tercapai atau pola perilaku dan strategi yang disukai dan diterapkan oleh seorang pemimpin. A Dale Timpe menyatakan bahwa gaya kepemimpinan sebagaimana yang dikemukakan oleh Bill Woods adalah:

a. Otokratis

Pemimpin otokratis membuat keputusannya sendiri karena kekuasaan terpusatkan dalam diri satu orang yang memikul tanggung jawab. Karena ia memikul tanggung jawab dan wewenang sacara penuh. Keputusan dipaksakan dengan menggunakan imbalan dan

\footnotetext{
${ }^{11}$ Ahmad Mushtafa Al-Maraghi, Terjemah Tafsir Al-Maraghi (Semarang: CV. Toha Putra, 1986), h. 119.

${ }^{12}$ Ara Hidayat dan Imam Machi, Pengelolaan Pendidikan (Bandung: Pustaka Educa, 2010), h. 117-118.
} 
bawahan memiliki kehawatiran akan dihukum. Karena apabila wewenang dari pemimpin otokratis menekan, bawahan merasa takut dan tidak pasti.

b. Demokratis

Pemimpin yang demokratis disebut juga pemimpin partisipatif, selalu berkomunikasi dengan kelompok mengenai masalah-masalah yang menarik perhatian mereka dan mereka dapat menyumbangkan sesuatu untuk menyelesaikan ikut serta dalam penetapan sasaran. Keikut sertaan bawahan ini mendorong komitmen anggota pada keputusab akhir. Walaupun keputusan masih tetap pada pemimpin, karena beberapa tanggung jawab yang dipikulnya.

c. Laissez faire (kendali bebas)

Pemimpin penganut gaya ini memberikan kekuasaan kepada bawahan. Kelompok dapat mengembangkan sasarannya sendiri dan memecahkan masalahnya sendiri. Pengarahan tidak ada atau hanya sedikit. Gaya ini biasanya tidak berguna tetapi dapat menjadi efektif dalam kelompok profesional yang termotivasi tinggi.

\section{Fungsi Kepemimpinan dan Manajemen di Sekolah}

Kepala sekolah sebagai seorang pemimpin seharusnya dalam praktik sehari-hari selalu berusaha memperhatikan dan mempraktikkan delapan fungsi kepemimpinan dalam kehidupan sekolah.

a. Dalam kehidupan sehari-hari kepala sekolah akan dihadapkan kepada sikap para guru, staf dan para siswa yang mempunyai latar belakang kehidupan, kepentingan serta tingkat sosial budaya yang berbeda sehingga tidak mustahil terjadi konflik antar individu bahkan antarkelompok.

b. Sugesti atau saran sangat diperlukan oleh para bawahan dalam melaksanakan tugas.

c. Dalam mencapai tujuan setiap organisasi memerlukan dukungan, dana, sarana dan sebagainya.

d. Kepala sekolah berperan sebagai katalisator, dalam arti mampu menimbulkan dan menggerakkan semangat para guru, staf dan siswa dalam pencapaian tujuan yang telah ditetapkan. 
e. Rasa aman merupakan salah satu kebutuhan setiap orang baik secara individual maupun kelompok.

f. Seorang kepala sekolah selaku pemimpin akan menjadi pusat perhatian, artinya semua pandangan akan diarahkan ke kepala sekolah sebagai orang yang mewakili kehidupan sekolah di mana, dan dalam kesempatan apapun.

g. Kepala sekolah pada hakikatnya adalah sumber semangat bagi para guru, staf dan siswa.

h. Setiap orang dalam kehidupan organisasi baik secara pribadi maupun kelompok, apabila kebutuhannya diperhatikan dan dipenuhi. ${ }^{13}$

\section{Kinerja Guru}

\section{a. Pengertian kinerja guru}

Istilah kinerja berasal dari kata job performance atau actual performance (prestasi kerja atau prestasi yang sesungguhnya yang dicapai oleh seseorang). ${ }^{14}$ Handoko dalam bukunya manajemen personalia dan sumberdaya mendefinisikan kinerja sebagai proses dimana organisasi mengevaluasi atau menilai prestasi kerja karyawan. Prawiro suntoro dalam bukunya Merry Dandian Panji mengemukakan bahwa kinerja adalah hasil kerja yang dapat dicapai seseorang atau sekelompok orang dalam suatu organisasi dalam rangka mencapai tujuan organisasi dalam periode waktu tertentu.

Anwar Prabu Mangku Negara mendefinisikan kinerja (prestasi kerja) adalah hasil kerja secara kualitas dan kuantitas yang dicapai oleh seorang pegawai dalam melaksanakan tugasnya sesuai dengan tanggungjawab yang diberikannya. ${ }^{15}$ Kinerja adalah perbuatan seseorang dalam mengemban tugas dan wewenang yang menjadi kewajiban dan tanggung jawabnya yang disertai dengan kemampuan dan keahlian profesi. Berdasarkan pengertian di atas dapat disimpulkan bahwa kinerja adalah sebagai hasil-hasil fungsi pekerjaan atau kegiatan seseorang atau kelompok dalam suatu organisasi yang

\footnotetext{
${ }^{13}$ Wahjosumidjo, Kepemimpinan Kepala Sekolah, h.106-109.

${ }^{14}$ Anwar Prabu Mangkunegara, Managemen Sumber Daya Manusia Perusahaan (Bandung: PT Remaja Rosda Karya, 2015), h. 67.

${ }^{15}$ Ibid., h. 67.
} 
dipengaruhi oleh berbagai factor untuk mencapai tujuan organisasi dalam periode waktu tertentu. ${ }^{16}$

Guru adalah "seorang yang mempunyai gagasan yang harus diwujudkan untuk kepentingan anak didik, sehingga menunjang hubungan sebaik-bainya dengan anak didik, sehingga menjunjung tinggi, mengembangkan dan menerapkan keutamaan yang menyangkut agama, kebudayaan dan keilmuan”. Kinerja pengajar atau guru adalah perilaku atau respons yang memberi hasil yang mengacu kepada apa yang mereka kerjakan ketika dia menghadapi suatu tugas. Kinerja tenaga pengajar atau guru menyangkut semua kegiatan atau tingkah laku yang dialami tenaga pengajar, jawaban yang mereka buat, untuk memberi hasil atau tujuan. ${ }^{17}$ Berdasarkan pengertian yang dikemukakan diatas dapat disimpulkan bahwa kinerja guru adalah prestasi yang dicapai oleh seorang guru dalam mengelola dan melaksanakan tugas pendidikan dan pengajaran sesuai dengan ukuran yang berlaku bagi pekerjaannya.

\section{b. Standar kinerja guru}

Penetapan standar proses pendidikan merupakan kebijakan yang sangat penting dan strategis untuk pemerataan dan peningkatan kualitas pendidikan. Melalui standar proses pendidikan setiap guru dan atau pengelola sekolah dapat menentukan bagaimana seharusnya proses pembelajaran berlangsung. Untuk mencapai standar pencapaian proses pendidikan melalui peningkatan dan perbaikan profesional guru serta mengoptimalkan peran guru dalam proses pembelajaran.

Dalam kamus besar bahasa Indonesia kompetensi berarti kewenangan (kekuasaan) untuk menentukan (memutuskan sesuatu). Pengertian dasar kompetensi (competency) yakni kemampuan atau kecakapan. ${ }^{18}$ Menurut Johnson yang dikutip dalam bukunya Wina

\footnotetext{
${ }^{16}$ Moh. Pabundu Tika, Budaya Organisasi dan Peningkatan Kinerja (Jakarta: PT Bumi Aksara, 2008), h. 121.

${ }^{17}$ Martinis Yamin dan Maisah, Standarisasi Kinerja Guru (Jakarta: Persada Press, 2010), h. 87.

${ }^{18}$ Hasan Alwi, et.al, Kamus Besar Bahasa Indonesia (Jakarta: Balai Pustaka, 2012), h. 584.
} 
Sanjaya menyatakan: "competency as rational performance which satisfactorily meets the objective for a desired condition". Menurutnya, kompetensi merupakan perilaku rasional guna mencapai tujuan yang dipersyaratkan sesuai dengan kondisi yang diharapkan. ${ }^{19}$ Menurut Muhammad Uzer Usman kompetensi berarti suatu hal yang menggambarkan kualifikasi atau kemampuan seseorang baik yang kualitatif maupun kuantitatif. ${ }^{20}$

Dalam Undang-Undang Nomor 14 Tahun 2005 Tantang Guru dan Dosen pasal 10 dikemukakan bahwa kompetensi guru itu mencakup kompetensi pedagogis, kompetensi kepribadian, kompetensi sosial, dan kompetensi profesional. ${ }^{21}$ Dalam PP RI No. 19 Tahun 2005 pasal 28 ayat 1 dijelaskan bahwa pendidikan harus memiliki kualifikasi akademik dan komperensi sebagai agen pembelajaran, sehat jasmani dan rohani, serta memiliki kemampuan untuk mewujudkan tujuan pendidikan nasional. ${ }^{22}$

Dari pengertian diatas dapat disimpulakan bahwa kompetensi guru adalah kemampuan dasar atau kecakapan yang harus dimiliki oleh seseorang guru yang berkaitan dengan tugas dan tanggung jawab sebagai pendidik untuk menentukan suatu hal serta memiliki kemampuan untuk mewujudkan tujuan pendidikan nasional. Pengelolaan adalah kemampuan atau ketrampilan untuk memperoleh suatu hasil dalam rangka mencapai tujuan melalui kegiatan orang lain. ${ }^{23}$

Jadi kompetensi pengelolaan pembelajaran adalah kemampuan atau ketrampilan guru dalam mengatur segala sesuatu yang berkaitan dengan proses mengajar di kelas mulai dari pembuka pelajaran sampai pada pelaksanaan penilaian dalam rangka mencapai tujuan pembelajaran. Sebagai pengelola pembelajaran (learning manajer),

${ }^{19}$ Wina Sanjaya, strategi Pembelajaran Berorientasi Standar Proses Pendidikan (Jakarta: Kencana Prenada Media Group, 2013), h. 17.

${ }^{20}$ Moh Uzzer Utsman, Menjadi Guru Profesional (Bandung: Rosdakarya, 2017), h.

4.

${ }^{21}$ Undang-Undang Guru dan Dosen No. 14 Tahun 2005, h. 7.

${ }^{22}$ Peraturan Pemerintah Republik Indonesia No. 19 Tahun 2005, h. 18.

${ }^{23}$ Sondang. P. Siagian, Filsafat Administrasi (Jakarta: Bumi Aksara, 2014), h. 5. 
guru berperan dalam menciptakan iklim belajar yang memungkinkan siswa dapat belajar secara nyaman.

Kompetensi ini merupakan salah satu kompetensi dasar yang harus dimiliki oleh guru, karena jika guru mampu melaksanakan tugas mengajarnya dengan baik, maka kinerja guru akan dikatakan baik pula. Dan kinerja itu sendiri dapat dilihat dari bagaimana seseorang guru dalam mengelola pembelajaran baik sebelum proses belajar mengajar berlangsung sampai pada saat proses pembelajaran. Sebagai mana pendapat berikut ini:

1) Menurut Nana Sudjana, kinerja guru terlihat dari keberhasilannya didalam meningkatkan proses dan hasil belajar, yang meliputi:

a) Merencanakan program belajar mengajar.

b) Melaksanakan dan mengelola proses belajar mengajar

c) Manilai kemajuan proses belajar mengajar

d) Menguasai bahan pelajaran. ${ }^{24}$

2) Syafrudin Nurdin, menjelaskan bahwa kinerja guru itu terlihat dari aktifitas yang dilakukan dalam mempersiapkan pengajaran dikelas, yang meliputi:

a) Mengidentifikasi secara cermat pokok bahasan atau sub pokok bahasan yang telah digariskan dalam kurikulum.

b) Menentukan kelas atau semester dan alokasi waktu yang akan digunakan.

c) Merumuskan tujuan intruksional umum.

d)Merumuskan tujuan intruksional khusus.

e) Merinci materi pelajaran yang didasarkan kepada bahan pengajaran dan GBPP dan TIK yang hendak dicapai.

f) Merencanakan kegiatan belajar mengajar secara cermat, jelas dan tegas, sistematis, logis sesuai dengan TIK dan materi pelajaran.

g) Mempersiapkan dan melakukan variasi dan kebutuhan siswa lainya. h)Memilih alat peraga, sumber bahan dari buku dan masyarakat.

${ }^{24}$ Nana Sudjana, Dasar-dasar Proses Belajar mengajar (Bandung: Sinar Baru Algesindo, 2014), h. 19. 
i) Merancang secara teliti prosedur penilaian dan evaluasi.

j) Menggunakan bahasa yang jelas, mudah dipahami dan sesuai dengan EYD.

k) Menyusun satuan pelajaran. ${ }^{25}$

3) Suryosubroto mengemukakan bahwa kinerja guru dapat dilihat dari tugas yang dilakukan berkenaan dengan pembelajaran atau proses belajar mengajar yang tercakup dalam 10 kompetensi guru, yaitu:

a) Menguasai bahan pelajaran

b) Mengelola program belajar mengajar

c) Mengelola kelas

d) Menggunakan media atau sumber

e) Menggunakan lndasan-landasan pendidikan

f) Mengelola interaksi-interaksi belajar mengajar

g) Menilai prestasi siswa

h)Mengenal fungsi layanan bimbingan dan penyuluhan di sekolah

i) Mengenal dan menyelenggarakan administrasi sekolah

j) Memahami prinsip-prinsip dan menafsirkan hasil penelitian pendidikan guna keperluan pengajaran. ${ }^{26}$

Kompetensi professional merupakan profil kemampuan dasar yang harus dimiliki guru. Kompetensi tersebut dikembangkan berdasarkan analisis tugas-tugas yang harus dilakukan guru. Oleh karena itu, sepuluh kompetensi tersebut secara operasional akan mencerminkan fungsi dan peranan guru dalam membelajarkan anak didik.

Dengan demikian, untuk memperoleh predikat kinerja guru dengan baik. Maka ada banyak hal yang harus dilakukan dan diperlihatkan guru dalam kegiatan proses belajar mengajarnya, baik pekerjaan yang sifatnya tertulis maupun yang tidak tertulis. Sehingga sebagai guru harus bisa memahami akan tugasnya sebagai pengelola pembelajaran, melaksanakannya, dan berhasil dalam mengajar sehingga tujuan pembelajaran dapat dicapai dengan baik sangat

${ }^{25}$ Syafrudin Nurdin dan Basyirudin Usman, Guru Profesional dan Implementasi Kurikulum, (Jakarta: Ciputat Press, 2003), h. 90-91.

${ }^{26}$ Suryosubroto, Proses Belajar Mengajar Di Sekolah (Jakarta: Rineka Cipta, 2009), h. 4-5. 
ditentukan oleh konsekuensi dan kepiawaian dalam memilih strategi mengajar.

\section{c. Faktor-faktor yang mempengaruhi kinerja guru}

Ada banyak sekali faktor yang mempengaruhi kinerja guru. Menurut Meier, perbedaan kinerja antara orang yang satu dengan yang lainnya didalam situasi kerja adalah perbedaan karakteristik dari individu. Disampung itu, orang yang sama dapat menghasilkan kinerja yang berbeda dalam situasi yang berbeda pula. Semua ini menerangkan bahwa kinerja itu pada garis besarnya dipengaruhi oleh dua hal, yaitu faktor individu dan faktor situasi.

Mulyasa mengungkapkan beberapa model faktor yang mempengaruhi pencapaian kinerja. Untuk memahami tentang kinerja tenaga kependidikan, berikut disajikan beberapa pendapat menurut pengertian operasional sebagai berikut:

a. Model Vroomian

Vroom mengemukakan bahwa "performance $=F$ (Ability $X$ Motivasion)”. Menurut model ini kinerja seseorang merupakan fungsi perkalian antara kemampuan (ability) dan motivasi. Hubungan perkalian tersebut mengandung arti bahwa: jika seseorang rendah pada salah satu komponen maka prestasi kerjanya akan rendah pula. Kinerja seseorang yang rendah merupakan hasil dari motivasi yang rendah dengan kemampuan yang rendah.

b. Model Lawler dan Porter

Lawler dan Porter mengemukakan bahwa: "performance $=$ Effort $X$ Ability $X$ Role perceptions". Effort adalah banyaknya energi yang dikeluarkan seseorang dalam situasi tertentu, abilities adalah karakteristik individu seperti intelegensi. Ketrampilan, sifat sebagai kekuatan potensial untuk berbuat dan melakukan sesuatu. Sedangkan role perceptions adalah kesesuaian antara usaha yang dilakukan seseorang dengan pandangan atasan lansung tentang yang harus dikerjakan.

c. Model Ander dan Butzin

Ander dan Butzin mengajukan model kinerja sebagai berikut: "Future performance = past performance + (Motivation X Ability)". 
Formula terakhir menunjukkan bahwa kinerja merupakan hasil interaksi antara motivasi dengan ability, orang yang tinggi abilitynya tetapi rendah motivasinya, akan menghasilkan kinerja yang rendah, demikian halnya orang yang bermotivasi tinggi tetapi ability-nya rendah. ${ }^{27}$

Dari beberapa pendapat diatas, penulis lebih sepakat menurut pendapat Lawler dan Porter yang mana seorang pendidik menjalankan tugas harus sesuai dengan sistem yang telah ditentikan dan hasilnya sesuai dengan apa yang ia usahakannya.

Anwar Prabu Mangkunegara mengungkapkan bahwa faktor yang mempengaruhi pencapaian kinerja adalah faktor kemampuan (ability) dan faktor motivasi (motivation).

Hal ini sesuai dengan pendapat Keith Davis yang merumuskan bahwa:

a) Humam performance $=$ ability + motivation.

b) Motivation = Attitude + situation.

c) Ability $=$ knowledge + skill. $^{28}$

Kemampuan (ability) pegawai terdiri dari kemampuan potensi (IQ) dan kemampuan reality (knowledge + skill). Artinya pegawai yang memiliki IQ diatas rata-rata dengan pendidikan yang memadai untuk jabatannya dan terampil dalam mengerjakan pejerjaan sehari-hari, maka ia akan lebih mudak mencapai kinerja yang diharapkan. Oleh karena itu, pegawai perlu ditempatkan pada pekerjaan yang sesuai dengan keahliannya (the right man in the right plece. The right man on the right job). ${ }^{29}$

Motivasi terbentuk dari sikap (attitude) seorang pegawai dalam menghadapi situasi kerja. Sikap mental merupakan kondisi mental yang mendorong diri pegawai untuk berusaha mencapai prestasi kerja secara maksimal. Sikap mental seorang pegawai harus sikap mental yang siap secara psikofisik (siap secara mental, fisik, tujuan dan situasi). Artinya seorang pegawai harus siap mental, mampu secara h. $136-137$.

${ }^{27}$ Mulyasa, Manajemen Berbasis Sekolah (Bandung: PT Remaja Rosdakarya, 2014),

${ }^{28}$ Anwar Prabu Mangkunegara, Managemen Sumber Daya, h. 67.

${ }^{29}$ Ibid., h. 67. 
fisik, memahami tujuan utama dan target kerja yang akan dicapai, mampu memanfaatkan, dan menciptakan situasi kerja. ${ }^{30}$

Menurut Syarif Mangkuprawira dan Aida Vitayala kinerja merupakan suatu kontruksi multi dimensi yang mencakup banyak faktor yang mempengaruhinya. Faktor-faktor tersebut terdiri atas faktor instrinsik guru (personal/individual) atau SDM dan ekstrinsik, yaitu kepemimpinan, sistem, tim, dan situasional. Uraian rincian faktor-faktor tersebut adalah sebagai berikut:

a) Faktor personal/individual, meliputi unsur pengetahuan, ketrampilan (skill), kemampuan, kepercayaan diri, motivasi, komitmen yang dimiliki oleh tiap individu guru.

b) Faktor kepemimpinan, meliputi aspek kualitas manajer dan tem leader dalam memberikan dorongan, semangat, arahan, dan dukungan kerja pada guru.

c) Faktor tim, meliputi kualitas dukungan dan semangat yang diberikan oleh rekan dalam satu tim, kepercayaan terhadap sesama anggota tim, kekompakan, dan keeratan anggota tim.

d) Faktor sistem, meliputi sistem kerja, fasilitas kerja yang diberikan oleh pimpinan sekolah, proses organisasi (sekolah) dan kultur kerja dalam organisasi (sekolah).

e) Faktor kontekstual (situasional), meliputi tekanan dan perubahan lingkungan eksternal dan internal. ${ }^{31}$

4. Hasil penelitian

a. Peran Kepala Sekolah Dalam Peningkatan Kinerja Guru

Kepala sekolah merupakan motor penggerak, penentu arah kebijakan sekolah, yang akan menentukan bagaimana tujuan-tujuan sekolah dan pendidikan pada umumnya direalisasikan. Dalam melaksankan tugas dan fungsinya, jajaran pimpinan pada dinas pendidikan termasuk kepala sekolah memiliki gaya kepemimpinan masing-masing, yang sangat mempengaruhi kinerja para tenaga kependidikan dilingkungan kerjanya masing-masing. Kegagalan dan keberhasilan sekolah banyak ditentukan oleh kepala sekolah, karena

${ }^{30}$ Ibid., h. 68.

${ }^{31}$ Martinis Yamin dan Maisah, Standarisasi Kinerja Guru, h. 129-130. 
kepala sekolah merupakan pengendali dan penentu arah yang hendak ditempuh oleh sekolah menuju tujuannya.

Hal ini sejalan dengan apa yang dikemukakan oleh Siagian dalam bukunya Mulyasa sebagai berikut: “Arah yang hendak ditempuh oleh organisasi menuju tujuannya harus sedemikian rupa sehingga mengoptimalkan pemanfaatan dari segala sarana dan prasarana yang tersedia itu. Arah yang dimaksud tertuang dalam strategi dan taktik yang disusun dan dijalankan oleh organisasi yang bersangkutan. Perumus dan penentu strategi dan taktik tersebut adalah pimpinan dalam organisasi tersebut". ${ }^{32}$

Agar proses pendidikan dapat berjalan efektif dan efisien, guru dituntut memiliki kompetensi yang memadai, baik dari segi jenis maupun isinya. Namun, jika di selami lebih dalam lagi tentang isi yang terkandung dari setiap jenis kompetensi, sebagaimana disampaikan oleh para ahli maupun dalam perspektif kebijakan pemerintah, kiranya untuk menjadi guru yang kompeten bukan sesuatu yang sederhana, untuk mewujudkan dan meningkatkan kompetensi guru diperlukan upaya yang sungguh-sungguh dan komprehensif.

Salah satu upaya yang dapat dilakukan adalah melalui optimalisasi peran kepala sekolah. Idochi Anwar dan Yayat Hidayat Amir mengemukakan bahwa " kepala sekolah sebagai pengelola memiliki tugas mengembangkan kinerja personel, terutama meningkatkan kompetensi profesional guru”. Perlu digarisbawahi bahwa yang dimaksud dengan kompetensi profesional di sini, tidak hanya berkaitan dengan penguasaan materi semata, tetapi mencakup seluruh jenis dan isi kandungan kompetensi.

Delapan peran utama kepala sekolah yaitu, sebagai : (1) manajer; (2) educator (pendidik); (3) administrator; (4) evaluator; (5) supervisor; (6) leadership (pemimpin); (7) inovator; dan (7) entrepreneurship. Merujuk kepada delapan peran kepala sekolah sebagaimana disampaikan di atas, di bawah ini akan diuraikan secara ringkas hubungan antara peran kepala sekolah dengan peningkatan kompetensi guru.

${ }^{32}$ Mulyasa, Manajemen Berbasis Sekolah, h. 158-159. 


\section{1) Kepala sekolah sebagai manajer}

Dalam mengelola tenaga kependidikan, salah satu tugas yang harus dilakukan kepala sekolah adalah melaksanakan kegiatan pemeliharaan dan pengembangan profesi para guru. Dalam hal ini, kepala sekolah seyogyanya dapat memfasiltasi dan memberikan kesempatan yang luas kepada para guru untuk dapat melaksanakan kegiatan pengembangan profesi melalui berbagai kegiatan pendidikan dan pelatihan, baik yang dilaksanakan di sekolah, seperti : MGMP/MGP tingkat sekolah, in house training, diskusi profesional dan sebagainya, atau melalui kegiatan pendidikan dan pelatihan di luar sekolah, seperti : kesempatan melanjutkan pendidikan atau mengikuti berbagai kegiatan pelatihan yang diselenggarakan pihak lain.

2) Kepala sekolah sebagai edukator (pendidik)

Kegiatan belajar mengajar merupakan inti dari proses pendidikan dan guru merupakan pelaksana dan pengembang utama kurikulum di sekolah. Kepala sekolah yang menunjukkan komitmen tinggi dan fokus terhadap pengembangan kurikulum dan kegiatan belajar mengajar di sekolahnya tentu saja akan sangat memperhatikan tingkat kompetensi yang dimiliki gurunya, sekaligus juga akan senantiasa berusaha memfasilitasi dan mendorong agar para guru dapat secara terus menerus meningkatkan kompetensinya, sehingga kegiatan belajar mengajar dapat berjalan efektif dan efisien.

\section{3) Kepala sekolah sebagai administrator}

Khususnya berkenaan dengan pengelolaan keuangan, bahwa untuk tercapainya peningkatan kompetensi guru tidak lepas dari faktor biaya. Seberapa besar sekolah dapat mengalokasikan anggaran peningkatan kompetensi guru tentunya akan mempengaruhi terhadap tingkat kompetensi para gurunya. Oleh karena itu kepala sekolah seyogyanya dapat mengalokasikan anggaran yang memadai bagi upaya peningkatan kompetensi guru.

4) Kepala sekolah sebagai evaluator

Untuk menilai kinerja guru dan staf sekolah dalam melaksanakan tugas pokok dan tanggung jawabnya untuk meningkatkan mutu pendidikan. Kepala sekolah membina guru dalam 
memanfaatkan hasil penilaian untuk perbaikan mutu pendidikan. Evaluasi merupakan pengukuran ketercapaian program pendidikan, perencanaan suatu program substansi pendidikan termasuk kurikulum dan pelaksanaannya, pengadaan dan peningkatan kempuan guru, pengelolaan pendidikan, dan reformasi pendidikan secara keseluruhan.

5) Kepala sekolah sebagai supervisor

Untuk mengetahui sejauh mana guru mampu melaksanakan pembelajaran, secara berkala kepala sekolah perlu melaksanakan kegiatan supervisi, yang dapat dilakukan melalui kegiatan kunjungan kelas untuk mengamati proses pembelajaran secara langsung, terutama dalam pemilihan dan penggunaan metode, media yang digunakan dan keterlibatan siswa dalam proses pembelajaran. Dari hasil supervisi ini, dapat diketahui kelemahan sekaligus keunggulan guru dalam melaksanakan pembelajaran, tingkat penguasaan kompetensi guru yang bersangkutan, selanjutnya diupayakan solusi, pembinaan dan tindak lanjut tertentu sehingga guru dapat memperbaiki kekurangan yang ada sekaligus mempertahankan keunggulannya dalam melaksanakan pembelajaran.

Jones dkk. sebagaimana disampaikan oleh Sudarwan Danim mengemukakan bahwa " menghadapi kurikulum yang berisi perubahan-perubahan yang cukup besar dalam tujuan, isi, metode dan evaluasi pengajarannya, sudah sewajarnya kalau para guru mengharapkan saran dan bimbingan dari kepala sekolah mereka”. Dari ungkapan ini, mengandung makna bahwa kepala sekolah harus betulbetul menguasai tentang kurikulum sekolah. Mustahil seorang kepala sekolah dapat memberikan saran dan bimbingan kepada guru, sementara dia sendiri tidak menguasainya dengan baik

\section{6) Kepala sekolah sebagai leadership (pemimpin)}

Dalam teori kepemimpinan ada dua gaya kepemimpinan yaitu kepemimpinan yang berorientasi pada tugas dan kepemimpinan yang berorientasi pada manusia. Dalam rangka meningkatkan kompetensi guru, seorang kepala sekolah dapat menerapkan kedua gaya kepemimpinan tersebut secara tepat dan fleksibel, disesuaikan dengan kondisi dan kebutuhan yang ada. 
Kepemimpinan seseorang sangat berkaitan dengan kepribadian dan kepribadian kepala sekolah sebagai pemimpin akan tercermin dalam sifat-sifat sebagai barikut : (1) jujur; (2) percaya diri; (3) tanggung jawab; (4) berani mengambil resiko dan keputusan; (5) berjiwa besar; (6) emosi yang stabil, dan (7) teladan.

7) Kepala sekolah sebagai inovator

Dalam kaitannya sebagi inovator kepala sekolah diharapkan mampu memberikan inovasi-inovasi baru dalam lembaga yang dipimpinnya. Karena melihat teknologi sekarang ini yang semakin maju, kepala sekolah diharapkan mampu mengadakan hal-hal yang baru untuk kemajuan pendidikan.

\section{8) Kepala sekolah sebagai enterpreneurship}

Dalam menerapkan prinsip-prinsip enterpreneurship dihubungkan dengan peningkatan kompetensi guru, maka kepala sekolah seyogyanya dapat menciptakan pembaharuan, keunggulan komparatif, serta memanfaatkan berbagai peluang. Kepala sekolah dengan sikap kewirauhasaan yang kuat akan berani melakukan perubahan-perubahan yang inovatif di sekolahnya, termasuk perubahan dalam hal-hal yang berhubungan dengan proses pembelajaran siswa beserta kompetensi gurunya.

Sejauh mana kepala sekolah dapat mewujudkan peran-peran di atas, secara langsung maupun tidak langsung dapat memberikan kontribusi terhadap peningkatan kompetensi guru, yang pada gilirannya dapat membawa efek terhadap peningkatan mutu pendidikan di sekolah. ${ }^{33}$

Dalam kaitannya dengan peran kepala sekolah dalam meningkatkan kinerja tenaga kependidikan, perlu dipahami bahwa setiap kepala sekolah bertanggung jawab mengarahkan apa yang baik bagi tenaga kependidikan, dan dia sendiri harus berbuat baik. Kepala sekolah juga harus menjadi contoh, sabar dan penuh pengertian. Fungsi pemimpin hendaknya diartikan seperti motto Ki Hajar

${ }^{33}$ Akhmad Sudrajat, Peran Kepala Sekolah dalam Meningkatkan Kompetensi Guru, http://www.psb-psma.org/content/blog/peran-kepala-sekolah-dalam-meningkatkankompetensi-guru. 
Dewantara: Ing ngarsa sung tulada, Ing madya mangun karsa, Tut wuri handayani (di depan menjadi teladan, di tengah membina kemauan, di belakang menjadi pendorong/memotivasi). ${ }^{34}$

Kepala sekolah merupakan motor penggerak, penentu arah kebijakan sekolah yang akan menentukan bagaimana tujuan-tujuan sekolah dan pendidikan pada umumnya direalisasikan, sehingga kepala sekolah dituntut untuk mempunyai taktik atau kiat yang tepat dan senantiasa meningkatkan efektifitas kinerjanya. Kepemimpinan kepala sekolah yang efektif dapat dilihat berdasarkan kriteria-kriteria berikut ini:

a. Mampu memberdayakan guru untuk melaksanakan proses pembelajaran dengan baik, lancar, dan produktif.

b. Dapat menyelesaikan tugas sesuai dengan waktu yang telah ditetapkan.

c. Mempu menjalin hubungan yang harmonis dengan masyarakat sehingga dapat melibatkan mereka secara aktif.

d. Berhasil menerapkan prinsip kepemimpinan yang sesuai dengan tingkat kedewasaan guru dan pegawai lainnya.

e. Bekerja dengan tim manajemen.

f. Berhasil mewujudkan tujuan sekolah secara produktif.

Perilaku kepala sekolah harus dapat mendorong kinerja para guru dengan menunjukkan rasa bersahabat, dekat, dan penuh pertimbangan terhadap para guru, baik sebagai individu maupun kelompok. Perilaku instrumental merupakan tugas-tugas yang diorientasikan dan secara langsung diklarifikasikan dalam peranan dan tugas-tugas para guru, sebagai individu dan sebagai kelompok. Perilaku kepala sekolah yang positif dapat mendorong dan memotivasi guru untuk bekerja sama dan meningkatkan kinerjanya dalam rangka mewujudkan tujuan pendidikan. Upaya atau kiat-kiat yang dapat dilakukan oleh kepala madrasah dalam meningkatkan kerja guru

${ }^{34}$ Mulyasa, Manajemen Berbasis Sekolah, h. 160. 
antara lain melalui, pembinaan disiplin tenaga kependidikan, pemberian motivasi, penghargaan. ${ }^{35}$

b. Tujuan dan Strategi kepemimpinan kepala sekolah dalam meningkatkan kinerja guru pada Lembaga Pendidikan Islam

Dalam rangka melakukan peran dan fungsinya sebagai manajer, kepala sekolah harus memiliki strategi yang tepat untuk memberdayakan tenaga kependidikan melalui kerja sama atau kooperatif. Memberi kesempatan kepada para tenaga kependidikan untuk meningkatkan profesinya dan mendorong keterlibatan seluruh tenaga kependidikan dalam berbagai kegiatan yang menunjang program sekolah.

a. Memberdayakan tenaga kependidikan melalui kerja sama atau kooperatif dimaksudkan bahwa dalam peningkatan profesionalisme tenaga kependidikan di sekolah, kepala sekolah harus mementingkan kerja sama dengan tenaga kependidikan dan pihak lain yang terkait dalam melaksanakan setiap kegiatan.

b. Memberi kesempatan kepada para tenaga kependidikan untuk meningkatkan profesinya, sebagai manajer kepala sekolah harus meningkatkan profesi secara persuasif dan dari hati ke hati.

c. Mendorong keterlibatan seluruh tenaga kependidikan, dimaksudkan bahwa kepala harus berusaha untuk mendorong keterlibatan semua tenaga kependidikan dalam setiap kegiatan di sekolah (partisipatif). ${ }^{36}$

Sejarah pertumbuhan peradapan manusia banyak menunjukkan bukti bahwa salah satu faktor yang menentukan keberhasilan dan keberlangsungan organisasi adalah kuat tidaknya kepemimpinan. Kegagalan dan keberhasilan suatu organisasi banyak ditentukan oleh pemimpin karena pemimpin merupakan pengendali dan penentu arah yang hendak ditempuh oleh organisasi menuju tujuan yang akan dicapai. Arah yang dimaksud tertuang dalam strategi dan taktik yang

\footnotetext{
${ }^{35}$ Mohamad Yasin Yusuf, Kepemimpinan Kepala Sekolah dalam Meningkatkan Kinerja Guru, File://D: / aq/ kepemimpinan-kepala-sekolah-17 html.

${ }^{36}$ Mulyasa, Menjadi Kepala Sekolah Profesional (Bandung: Remaja Rosdakarya, 2009), h.103-104.
} 
disusun dan dijalankan oleh organisasi bersangkutan. Perumus serta penentu strategi dan taktik adalah pemimpin dalam organisasi tersebut. Kepala sekolah sebagai pemimpin harus memiliki kemampuan diantaranya yang berkaitan dengan disiplin pegawai, motivasi, dan penghargaan.

\section{1) Pembinaan disiplin}

Seorang pemimpin harus mampu menumbuhkan disiplin, terutama disiplin diri (self-discipline). Dalam kaitan ini, pemimpin harus mampu membantu pegawai mengembangkan pola dan meningkatkan standar perilakunya, serta menggunakan pelaksanaan aturan sebagai alat untuk menegakkan disiplin. Disiplin merupakan sesuatu yang penting untuk menanamkan rasa hormat terhadap kewenangan, menanamkan kerjasama, dan merupakan kebutuhan rasa hormat terhadap orang lain.

Taylor and User dalam bukunya Mulyasa mengemukakan strategi umum membina disiplin sebagai berikut.

1) Konsep diri; strategi ini menekankan bahwa konsep-konsep diri setiap individu merupakan faktor penting dari setiap perilaku. Untuk menumbuhkan konsep diri, pemimpin disarankan bersifat empatik, menerima, hangat, dan terbuka sehingga para pegawai dapat mengeksplorasikan pikiran dan perasaannya dalam memecahkan masalahnya.

2) Keterampilan berkomunikasi; pemimpin harus menerima perasaan pegawai dengan teknik komunikasi yang dapat menimbulkan kepatuhan dari dalam dirinya.

3) Konsekuensi-konsekuensi logis dan alami; perilaku-perilaku yang salah terjadi karena pegawai telah mengembangkan kepercayaan yang salah terhadap dirinya. Hal ini mendorong munculnya perilaku-perilaku salah yang disebut misbehavior. Untuk itu pemimpin disarankan: a) menunjukkan secara tepat tujuan perilaku yang salah sehingga membantu pegawai dalam mengatasi perilakunya, serta b) memanfaatkan akibat-akibat logis dan alami dari perilaku yang salah. 
4) Klarifikasi nilai; strategi ini dilakukan untuk membantu pegawai dalam menjawab pertanyaannya sendiri tentang nilai-nilai dan membentuk sistem nilainya sendiri.

5) Latihan keefektifan pemimpin; metode ini bertujuan untuk menghilangkan metode represif dan kekuasaan, misalnya hukuman dan ancaman melalui model komunikasi tertentu.

6) Terapi realitas; pemimpin perlu bersukap positif dan bertanggungjawab.

Untuk menerapkan berbagai strategi tersebut, kepala sekolah harus mempertimbangkan berbagai situasi, dan perlu memahami faktor-faktor yang mempengaruhinya.

\section{2) Pembangkitan motivasi}

Keberhasilan suatu organisasi atau lembaga dipengaruhi oleh berbagai faktor, baik faktor yang datang dari dalam maupun yang datang dari lingkungan. Dari berbagai faktor tersebut, motivasi merupakan suatu faktor yang cukup dominan dan dapat menggerakkan faktor-faktor lain kearah efektivitas kerja. Dalam hal tertentu motivasi sering disamakan dengan mesin dan kemudi mobil, yang berfungsi sebagai penggerak dan pengarah.

Setiap pegawai memiliki karakteristik khusus, yang satu sama lain berbeda. Hal tersebut memerlukan perhatian dan pelayanan khusus pula dari pemimpinnya, agar mereka dapat memanfaatkan waktu untuk meningkatkan kinerjanya. Perbedaan pegawai tidakhanya dalam bentuk fisik, tetapi juga dalam spikisnya, misalnya motivasi. Oleh karena itu, untuk meningkatkan kinerja, perlu diupayakan untuk membangkitkan motivasi para pegawai dan faktor-faktor lain yang mempengaruhinya.

Motivasi merupakan salah satu faktor yang turut menentukan keefektifan kerja. Callahan and Clark mengemukakan bahwa motivasi adalah tenaga pendorong atau penarik yang menyebabkan adanya tingkah laku kearah tujuan tertentu. Mengacu pada pendapat tersebut, dapat dikemukakan bahwa motivasi merupakan suatu bagian yang sangat penting dalam suatu lembaga. Para pegawai akan bekerja dengan sungguh-sungguh apabila memiliki motivasi yang sangat tinggi. Apabila para pegawai memiliki motivasi yang positif, ia akan 
memperlihatkan minat, mempunyai perhatian, dan ingin ikut serta dalam suatu tugas atau kegiatan. Dengan kata lain, seorang pegawai akan melakukan semua pekerjaan dengan baik apabila ada faktor pendorong (motivasi). Dalam kaitan ini pemimpin dituntut untuk memiliki kemampuan membangkitkan motivasi para pegawai sehingga kinerja mereka meningkat. ${ }^{37}$

3) Penghargaan

Penghargaan (rewards) sangat penting untuk meningkatkan kegiatan yang produktif dan mengurangi kegiatan yang kurang produktif. Dengan penghargaan, pegawai akan terangsang untuk meningkatkan kinerja yang positif dan produktif. Penghargaan ini akan bermakna apabila dikaitkan dengan prestasi pegawai secara terbuka sehingga setiap pegawai memiliki peluang untuk meraihnya. Penggunaan penghargaan ini perlu dilakukan secara tepat, efektif, dan efisien agar tidak menimbulkan dampak negatif. ${ }^{38}$

\section{Penutup}

Dari berbagai penjelasan di atas dapat disimpulkan bahwa kepala sekolah sebagai pemimpin pendidikan harus dapat mengenal dan mengerti berbagai kedudukan, keadaan dan apa yang diinginkan baik oleh guru maupun oleh pegawai tata usaha serta pembantu lainya. Sehingga dengan kerja sama yang baik menghasilkan pikiran yang harmonis dalam usaha perbaikan sekolah. Kegagalan mencerminkan kurang berhasilnya perilaku serta peranan kepemimpinan seorang kepala sekolah. Semua ini perlu menjadi bahan timbangan bagi seorang kepala sekolah untuk menggerakkan seluruh anggota yang dipimpinnya.

Guru merupakan komponen manusiawi dalam proses belajar mengajar yang sangat berperan dalam mengantarkan siswa-siswanya pada tujuan pendidikan yang telah ditentukan. Gurulah yang memikul tanggung jawab atas keberhasilan dan kegagalan program pengajaran.

${ }^{37}$ Mulyasa, Manajemen Berbasis Sekolah (Bandung: PT Remaja Rosdakarya, 2014), h. 117-120.

${ }^{38}$ Ibid., h. 125-126. 
Oleh karena itu, mengajar adalah pekerjaan profesional karena menggunakan teknik dan prosedur yang berpijak pada landasan intelektual yang harus dipelajari secara sengaja, terencana dan kemudian dipergunakan demi kemaslahatan orang lain.

\section{Daftar Pustaka}

Ahmad Mushtafa Al-Maraghi. Terjemah Tafsir Al-Maraghi. Semarang: CV. Toha Putra, 1986.

Akhmad Sudrajat. Peran Kepala Sekolah dalam Meningkatkan Kompetensi Guru. http://www.psb-psma.org/content/blog/perankepala-sekolah-dalam-meningkatkan-kompetensi-guru.

Anwar Prabu Mangkunegara. Managemen Sumber Daya Manusia Perusahaan. Bandung: PT Remaja Rosda Karya, 2015.

Ara Hidayat dan Imam Machi. Pengelolaan Pendidikan. Bandung: Pustaka Educa, 2010.

Hasan Alwi, et.al. Kamus Besar Bahasa Indonesia. Jakarta: Balai Pustaka, 2012.

Kementrian Agama RI. Al-Qur'an dan Terjemahnya. Semarang: PT. Thoha Putra, 2008.

M. Ngalim Purwanto. Administrasi dan Supervisi Pendidikan. Bandung: PT. Remaja Rosdakarya, 2008.

Martinis Yamin dan Maisah. Standarisasi Kinerja Guru. Jakarta: Persada Press, 2010.

Miftah Toha. Kepemimpinan Dalam Manajemen. Jakarta: Rajawali Pers, 2010. 
Moh Uzzer Utsman. Menjadi Guru Profesional. Bandung: Rosdakarya, 2017.

Moh. Pabundu Tika. Budaya Organisasi dan Peningkatan Kinerja. Jakarta: PT Bumi Aksara, 2008.

Mohamad Yasin Yusuf. Kepemimpinan Kepala Sekolah dalam Meningkatkan Kinerja Guru. File:///D: / aq/ kepemimpinankepala-sekolah-17 html.

Mulyasa. Manajemen Berbasis Sekolah. Bandung: PT Remaja Rosdakarya, 2014.

Mulyasa. Menjadi Kepala Sekolah Profesional. Bandung: Remaja Rosdakarya, 2009.

Nana Sudjana. Dasar-dasar Proses Belajar mengajar. Bandung: Sinar Baru Algesindo, 2014.

Peraturan Pemerintah Republik Indonesia No. 19 Tahun 2005.

Saiful Sagala. Manajemen Strategic Dalam Peningkatan Mutu Pendidikan. Bandung: Alfabeta, 2009.

Soetjipto dan Raflis Kosasi, Profesi Keguruan. Jakarta: PT Rineka Cipta, 2009.

Sondang. P. Siagian. Filsafat Administrasi. Jakarta: Bumi Aksara, 2014.

Suryosubroto. Proses Belajar Mengajar Di Sekolah. Jakarta: Rineka Cipta, 2009.

T. Hani Handoko. Manajemen. Yogyakarta: BPFE, 2012.

Tony Bush dan Marianne Coleman. Manajemen Strategi Kepemimpinan Pendidikan, terj. Fahrurrozi. Yogyakarta: Ircisod, 2008. 
Istikomah

Undang-Undang Guru dan Dosen No. 14 Tahun 2005.

Wahjosumidjo. Kepemimpinan Kepala Sekolah, Tinjauan Teoritik dan Permasalahanya. Jakarta: Rajawali Pres, 2013, Cet. 9.

Wina Sanjaya. Strategi Pembelajaran Berorientasi Standar Proses Pendidikan. Jakarta: Kencana Prenada Media Group, 2013. 